

\title{
Mercury and methylmercury concentrations in high altitude lakes and fish (Arctic charr) from the French Alps related to watershed characteristics
}

Nicolas Marusczak, Catherine Larose, Aurélien Dommergue, Serge Paquet, Jean-Sébastien Beaulne, Régine Maury-Brachet, Marc Lucotte, Rachid Nedjaï, Christophe P. Ferrari

\section{To cite this version:}

Nicolas Marusczak, Catherine Larose, Aurélien Dommergue, Serge Paquet, Jean-Sébastien Beaulne, et al.. Mercury and methylmercury concentrations in high altitude lakes and fish (Arctic charr) from the French Alps related to watershed characteristics. Science of the Total Environment, 2011, 409, pp.1909-1915. halshs-00578858

\section{HAL Id: halshs-00578858 \\ https://shs.hal.science/halshs-00578858}

Submitted on 28 Mar 2011

HAL is a multi-disciplinary open access archive for the deposit and dissemination of scientific research documents, whether they are published or not. The documents may come from teaching and research institutions in France or abroad, or from public or private research centers.
L'archive ouverte pluridisciplinaire HAL, est destinée au dépôt et à la diffusion de documents scientifiques de niveau recherche, publiés ou non, émanant des établissements d'enseignement et de recherche français ou étrangers, des laboratoires publics ou privés. 
1 Mercury and methylmercury concentrations in high altitude lakes

2 and fish populations from the French Alps related to watershed

3

4

5 Nicolas Marusczak ${ }^{a}, b$, Catherine Larose ${ }^{a}$, Aurélien Dommergue ${ }^{a}$, Serge Paquet ${ }^{c}$, Jean-

6 Sébastien Beaulne ${ }^{c}$, Marc Lucotte $^{c}$, Rachid Nedjai ${ }^{b}$, and Christophe.P Ferrari ${ }^{a}$.

7

8

\section{characteristics}

aLaboratoire de Glaciologie et Géophysique de l'Environnement (LGGE) CNRS UMR 5183, 54, rue Molière, Domaine Universitaire, B.P. 96, 38402 Saint Martin d'Hères, France

${ }^{b}$ Politiques publiques, Action politique, Territoires (PACTE) CNRS UMR 5194 - Université Pierre Mendès-France Grenoble II - Institut d'Études Politiques de Grenoble - Université Joseph Fourier - Grenoble I

'Université du Québec à Montréal, GEOTOP, CP 8888, Succ. Centre-Ville, Montréal (Québec), Canada H3C 3P8

*Corresponding author phone: +33 4768242 24; fax +33 4768242 01;

e-mail:nicolas.marusczak@doctorant.univ-grenoble.fr

\section{Abstract}

Keywords : Mercury, methylmercury, lakes, fish population, French Alps. 


\section{Introduction}

Mercury is a toxic metal for human and environment, which can be transported on long distant from its emission sources and can contaminate aquatics environment. Emitted by both natural and anthropogenic sources (Pacyna et al., 2006), elemental gaseous mercury $\left(\mathrm{Hg}^{0}\right)$, predominant form in the atmosphere, can join remote areas, like altitude lakes, mainly by atmospheric transport. $\mathrm{Hg}^{0}$, can be oxidized to divalent mercury $\left(\mathrm{Hg}^{2+}\right)$ and deposited onto surfaces and contaminate different reservoirs like catchments and water. Once deposited, one fraction of $\mathrm{Hg}^{2+}$ can be methylated by both biotic (Pongratz and Heumann, 1999) and abiotic pathways (Celo et al., 2006) leading to an organo-metallic form: methylmercury (MeHg). This form is very toxic and is able to both accumulate in living organisms and to biomagnify through the food web. Mercury contamination in fish population can be extremely variable, due to the nature of ecosystems (Bjorklund et al., 1984; Drevnick et al., 2007; Lindeberg et al., 2007) . MeHg sources to lakes are numerous and known. The principal sources are atmospheric, via dry and wet deposition (Graydon et al., 2008), the runoff from watershed, - and thus meltwater (Loseto et al., 2004) -, and in-situ production of MeHg by microbial activities in water column and sediment, especially by sulfate-reducing bacteria (SRB) present in anoxic sediments (Compeau, 1985; Warner et al., 2003). Now, It is known, that watershed composition influences the production and accumulation of methylmercury by aquatic organism (Belger and Forsberg, 2006; Bonzongo and Lyons, 2004; Warner et al., 2005). Therefore, high mercury concentrations in environment not signify that fish population will be highly contamined. Indeed, watershed composition (Warner et al., 2005) or lakes water with an important organic matter can promote mercury methylation (Ribeiro Guevara et al., 2008) (REF). Therefore, a catchments with abundant vegetation, is susceptible to increase MeHg concentration in water column. It is also known, that mercury and methylmercury concentration increase with size of ecosystem and also with trophic position of fish. More food chain is long, more methylmercury concentration measured in fish will be important. This, can be explained by the fact that methylmercury is bioaccumulable in the organism. However, a study conducted by (Ward et al., 2010), using a large-scale field experiment, examining the relationship between $\mathrm{Hg}$ concentrations and growth rate in fish and demonstrates that the variability of mercury concentrations in fish explained by the concentrations of mercury measured in these fish prey, but also by the rate of growth. Indeed, a fast-growing fish are less contaminated than the small fish. These studies show that several factors influence the contamination of fish populations. Lavigne et al (Lavigne et al., 2010, In Press) show again that growth rates influence mercury contamination in fishes. A study conducted in Sweden (Lindqvist et al., 1991), shows that despite the reduction of emissions of $\mathrm{Hg}$ in Sweden during the 1970's and 1980's, mercury contaminations in fish populations increase slightly. 
Rognerud et al. (2005) (Rognerud et al., 2005) studied the contamination of mercury and organochlorine in fish from high elevation lakes in Europe. Results show mercury concentrations in fish populations rather low $\left(0.02 \mu \mathrm{g} \cdot \mathrm{g}^{-1}\right)$. Several explanations are mentioned by the authors to explain these low mercury levels : i) a trophic level low of fish population studied, ii) a flow of $\mathrm{Hg}$ in sediments low, and iii) a low rates of methylation in the cold and clear lakes. However, Blais et al., (Blais, 2006), shows in a study conducted in the Pyrenees, the existence of a relationship between altitude lakes and mercury contamination. The authors suggest that enhanced deposition and/or retention of mercury is taking place in high-altitude aquatic foodwebs. Despite some studies conducted in Europe, no study was conducted in the French Alps on mercury contamination in fish population.

Here, we present the results of a study conducted in four lakes situated in the French Alps (Bramant lakes, Crop lake, la Sagne lake and Poursollet lake). The main objectives of this paper are to understand and explain mercury contamination in fish population and understand the influence of watershed composition in altitude.

\section{Methods}

\subsection{Site description:}

The four lakes studied are situated in the French Alps, in particularly in "Belledonne Massif" and "Grandes Rousses Massif". For this study we have selected, the Bramant Lake $\left(45^{\circ} 12^{\prime} 00^{\prime \prime} \mathrm{N}\right.$,

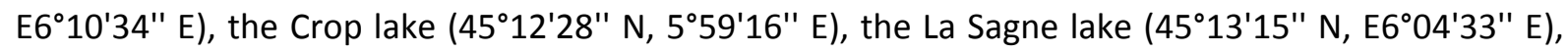
and Poursollet Lake $\left(45^{\circ} 03^{\prime} 08^{\prime \prime} \mathrm{N}, \mathrm{E} 5^{\circ} 54^{\prime} 00^{\prime \prime} \mathrm{E}\right)$. The altitude of lakes is respectively $2448 \mathrm{~m}, 1906 \mathrm{~m}$, $2067 \mathrm{~m}$ and $1648 \mathrm{~m}$ above sea level (a.s.l.) and their distance from Grenoble is $\sim 35 \mathrm{~km}, \sim 20 \mathrm{~km}, \sim 27$ $\mathrm{km}, \sim 21 \mathrm{~km}$, respectively. The different types of land cover were assessed using matricial Landsat 7 satellite images. The snapshots were interpolated to cover the whole region using GRASS 6.0, and then analyzed with Quantum GIS for vegetation coverage. Six classes of coverage were considered, including tree population, wild grass, land, rock, ice/snow and lakes. The resulting is presented in figure 1. Table 1 resume different information of these 4 lakes, and figure 1 show watershed composition of each lake and the study area.

\subsection{Water samples and analysis:}

Water column have been sampled in September 2008 for analyses of Total mercury and Methylmercury. Water column is sampled using a Niskin ${ }^{\text {TM }}$ bottle, and each sample are collected in acid-washed $250 \mathrm{~mL}$ Teflon bottles for THg and in acid-washed $125 \mathrm{~mL}$ Teflon bottle for MeHg using clean sampling techniques (Ferrari et al., 2000). All water samples were maintained frozen at $-20^{\circ} \mathrm{C}$ and in the dark until analysis. 
105 Each sample of water was oxidised with $0,5 \%$ o $(\mathrm{v} / \mathrm{v})$ of $\mathrm{BrCl}$ to dissociate all the mercury complexes 106 and to oxidize $\mathrm{THg}$ to divalent form, $\mathrm{Hg}^{2+}$. Excess $\mathrm{BrCl}$ was neutralized with hydroxylamine hydrochloride $(0,5 \% \mathrm{v} / \mathrm{v})$, and $\mathrm{THg}$ was determined using cold vapor atomic fluorescence spectrometry after reduction of $\mathrm{Hg}^{2+}$ to $\mathrm{Hg}^{0}$ by stannous chloride (Bloom and Crecelius, 1983), using a Tekran 2600 analyser (Tekran Inc.) according to EPA method 1631 revision E, with a detection limit of $0.1 \mathrm{ng} . \mathrm{L}^{-1}$. Each sample was analyzed in triplicate. THg concentrations are presented as mean \pm 1 standard deviation.

\subsubsection{Methylmercury analysis}

MeHg concentrations were determined by capillary gas chromatography coupled with atomic fluorescence spectrometry (GC-AFS) as described by Cai et al., (Cai et al., 1996) and is briefly described here. The determination of organomercury in water samples involves an adsorbent preconcentration of the organomercurials onto sulfydryl-cotton fibers followed by elution with acidic $\mathrm{KBr}$ and $\mathrm{CuSO}_{4}$ and extraction in methylene chloride.

\subsection{Fish sample and analysis:}

All lakes have been fished using three different experimental nets of $20 \mathrm{~m}$ length with mesh size of 15, 20 or $27 \mathrm{~mm}$ were used for fish collection. Fish species, total length $(\mathrm{mm})$, weight $(\mathrm{g})$, sex, were determined for all specimens whenever possible. The anatomic structures needed for age determination were also collected. A piece of fish muscle was taken from the caudal region for mercury analysis. Pieces of fish flesh were conserved frozen at $-20^{\circ} \mathrm{C}$ and in the dark until analysis.

\subsubsection{Age determination}

Age determinations were determined using operculum method (Campbell and Babaluk 1979; Pépin and Lévesque 1985; Babaluk and Campbell 1987; Babaluk et al. 1993). All age estimations were performed at least twice - usually by two different and independent readers - or until agreement was reached on an age value. If disagreement persisted on the age value after the third reading, the structure was discarded and the age data rejected.

\subsubsection{Total mercury analysis}

Total $\mathrm{Hg}$ concentrations in the fish muscles were determined by flameless atomic absorption spectrometry. Analyses were carried out automatically after drying by thermal decomposition at $750^{\circ} \mathrm{C}$, under an oxygen flow (AMA 254; Leco-France). The validity of the analytical method was 
(TORT-2, lobster hepatopancreas from NRCC-CNRC, Ottawa, Canada). Hg values were consistently within the certified ranges.

\subsubsection{Fish standardized length}

The average fish lengths were calculated for each lake, and the mean value of all lakes was calculated according to the distribution of averages for all lakes. The three mean values obtained were then used for modeling at standardized length $\left(L_{s t d}\right)$ rounded at the nearest $210 \mathrm{~mm}$. In this study, $L_{\text {std }}$ values act as modeling constants for each lake under study.

\section{Results}

\subsection{Total mercury and methylmercury concentrations in water column.}

Figure 2 shows THg and MeHg concentrations in water column on the four lakes studied: Bramant Lake, Crop Lake, La Sagne Lake and Poursollet Lake in September 2008. THg and MeHg concentrations measured are low compared to others studies. For Bramant Lake (figure2a), THg concentrations profiles are obtained on depth of 19 meters. THg concentrations in water surface is inferior to detection limit $\left(<0.1 \mathrm{ng} \cdot \mathrm{L}^{-1}\right)$. In the water column, THg concentrations range between 1.5 and detection limit $\left(<0.1 \mathrm{ng} . \mathrm{L}^{-1}\right)$. For $\mathrm{MeHg}$, levels are between $2.1 \mathrm{pg} . \mathrm{L}^{-1}$ and $3.7 \mathrm{pg} . \mathrm{L}^{-1}$ for the first twelve meters. After we observe an increase up to 16 meters where methylmercury levels increase from $3.6 \mathrm{pg} \cdot \mathrm{L}^{-1}$ to $9.3 \mathrm{pg} \cdot \mathrm{L}^{-1}$. Then we have a significant decrease until to 18 meters, with a methylmercury concentration of $3.7 \mathrm{pg} \cdot \mathrm{L}^{-1}$.

Regarding Crop lake (figure 2b), profiles is obtained with a depth of 29 meters. With our detection limit, we measure only THg on surface and at 2 meters deep, corresponding to a concentration of 0.1 ng. $\mathrm{L}^{-1}$ and $0.9 \mathrm{ng} \cdot \mathrm{L}^{-1}$ respectively. Others depth, THg concentrations is not detected by our analyze method. The methylmercury concentrations in water column from Crop lake range between 1.90 to $9.06 \mathrm{pg} . \mathrm{L}^{-1}$. In detail, until ten meters, we observe an increase of methylmercury levels until $9.06 \mathrm{pg} . \mathrm{L}^{-}$ ${ }^{1}$, and then methylmercury concentrations decrease to $3.02 \mathrm{pg} . \mathrm{L}^{-1}$ until 20 meters. After we observe an increase until to 29 meters deep to reach a methylmercury concentration of $8.97 \mathrm{pg} \cdot \mathrm{L}^{-1}$.

Figure 2c, shows THg concentration profiles to La Sagne lake until to 17 meters of depth. THg concentrations measured are relatively high compared to others lakes. In surface we measured a concentration of $3.12 \mathrm{ng} . \mathrm{L}^{-1}$ then, THg levels decrease until 8 meters to reach $1.69 \mathrm{ng} . \mathrm{L}^{-1}$. From 8 meters concentrations increase to reach a maximum of $4.34 \mathrm{ng} \cdot \mathrm{L}^{-1}$ at 10 meters deep. Then, $\mathrm{THg}$ levels decrease until 17 meters to reach $2.97 \mathrm{ng} . \mathrm{L}^{-1}$. Regarding MeHg concentrations in water column, we observe a MeHg concentration not homogeneous, concentrations range between 2.19 to $6.61 \mathrm{pg} \cdot \mathrm{L}^{-1}$. 
172 Figure 2c shows THg and MeHg profiles for Poursollet lake. THg and Mehg profile is obtained on 173 depth of 5 meters with an increase of THg concentration with depth. THg concentrations increase with depth. In surface water, we measure $0.4 \mathrm{ng} \cdot \mathrm{L}^{-1}$ until $1.5 \mathrm{ng} \cdot \mathrm{L}^{-1}$ to 5 meters of depth. Concerning MeHg levels, we measured concentrations range 4.73 to $9.21 \mathrm{pg} . \mathrm{L}^{-1}$. Maximum is measured to 4 meters deep (9.21 pg. $\mathrm{L}^{-1}$.).

177

\section{2. $\mathrm{THg}$ muscle concentration in fish}

Different species of fishes are caught during this fishing campaign. We caught a total of 109 fishes, including Salvelinus alpinus $(n=66)$, Salvelinus namaycush $(n=32)$, Oncorhynchus mykiss $(n=10)$ and Salmo trutta fario $(n=1)$. We have sample a portion of caudal muscle, for determination of THg and MeHg. For a standard length of $210 \mathrm{~mm}$, statistical analysis shows that no difference exists between species in each lakes regarding THg concentration in muscle. That's why, we can compared each lake, considering the fish community. Figure 3 shows different concentrations obtained for each lake, for a standard length of $210 \mathrm{~mm}$. We can observe that there is no difference for La Sagne, Crop and Poursollet lake, with THg concentration of $0.19,0.21,0.14 \mathrm{mg} . \mathrm{kg}^{-1}$, respectively. Regarding fishes of Bramant Lake, we note no difference with fishes of Poursollet Lake, but a significant difference with La Sagne and Crop Lake. Regarding

\section{Discussion}

\subsection{Total mercury and methylmercury concentrations in lakes.}

Results presented in this study show mercury and methylmercury concentrations in water column relatively low, but similar compared to small lakes situated in U.S.A (Barbiaz and Andren, 1995; Monson and Brezonik, 1998). In surface water, mercury comes mainly from atmospheric deposition (dry or wet), runoff and groundwater (Driscoll et al., 2007). In altitude, lakes are covered by snow and ice during 6-7 months a year (December to June), and the main water supply for the lake are runoff and melt water. These waters are drained by watershed and we know that the transport of mercury is primarily mediated by dissolved organic carbon (DOC), a leading carrier of mercury through the watershed (Grigal, 2002). Also, a forest or vegetation coverage on watershed, promote mercury absorption and may be leached in throughfall (Lindberg et al 2005). Three lakes studied have few vegetation and forest coverage. The watershed composition is mainly composed of rocks (Figure X). Mercury can be eluted more easily (not retained by vegetation and forest that could be the watershed, and therefore the organic matter) in the direction of Lake. In addition, the renewal of the lake in summer is very important, In particular with via runoff resulting mainly meltwater. When the ice cover melts, and that the runoff joins the lake, lake volume increases rapidly and a brewing of water occurs, allowing for a substantial renewal of the lake waters. As a result, mercury arriving 
mainly via runoff in lake is evacuated quickly by effluent. Therefore, mercury present in the lake has too little time to reside in the water column or to deposit in the lake bottom. Thus, possibility of mercury methylation is also low. In addition, these lakes are dimitics, that is to say, that we observe two stratifications by year: an inverse stratification in winter when lake is frozen, and a thermal stratification in warm season. We know that when a lake is stratified, the hypolimnion (water layer situated at the bottom of lake and above the sediment) becomes anoxic, which may promote mercury méthylation (REF). Now, on the profiles observe (figure $\mathrm{x}$ ), we see that methylmercury concentration not excess $2 \%$ of total mercury. We know that an important brewing and renewal of the lake water occurs in summer, that why, the hypolimnion is anoxic too little time, which reduce the possibility of mercury methylation.

Runoff may come from others lakes situated in watershed. In the four lakes studied (Bramant lake, La Sagne lake, Poursollet Lake and Crop lake), mercury concentrations are never greater than $0.5 \mathrm{ng} . \mathrm{L}^{-1}$ for 3 lakes, exept La Sagne lake, where mercury concentration in surface water is equal to $3.12 \mathrm{ng} \cdot \mathrm{L}^{-1}$. This difference can be explained by the fact that La Sagne lake is situated in the watershed composed of numerous lakes connected together (figure 1). Here, La Sagne Lake is a lake of order 5 . It is known, that the lake order can be affect total mercury contamination. That's why we can consider that the difference between mercury concentrations in water column of each lake, may be due to an accumulation of mercury from water of different runoff situated upstream of La Sagne Lake. To explore possible inputs of total mercury to La Sagne Lake by runoff, we have sampled runoff water. Results confirmed that we have a runoff contribution of total mercury in water of La Sagne Lake. Indeed, mercury concentrations measured in runoff are similar to mercury concentration in surface water and water column.

Finally, we cannot exclude the fact that the low mercury and methylmercury concentration in water, can be due to a reduction of ions $\mathrm{Hg}$ to $\mathrm{Hg}^{0}$ by photochemical process (Amyot et al., 1997) or by a microbial activities in water column.

\subsection{Total mercury concentration in fish population}

Total mercury concentrations in fish population, for a standard length of $210 \mathrm{~mm}$, showed in this study are relatively low (inferior to $0.22 \mathrm{mg} \cdot \mathrm{kg}^{-1}$ ) and not exceeded $0.5 \mathrm{mg} . \mathrm{Kg}^{-1}$, fish consumption advisory limit established for mercury by the World Health Organization. In addition, there are similar to others studies in Europe for all lakes (Blais, 2006; Rognerud et al., 2005). In these studies, Blais et al., show that in The French Pyrénées, the altitude can be a factor explaining mercury concentration in fish population. In fact, authors explain that in altitude, deposition and/or retention of $\mathrm{Hg}$ is more important, that why mercury concentration in fish are higher in altitude. However, in our study, with a range elevation of 800 meters, we observe no difference with mercury 
concentration in fish population between three lakes (Crop Lake, La Sagne Lake and Poursollet Lake). Instead, Bramant Lake located at $2448 \mathrm{~m}$ a.s.I (lake more elevated), is lake where mercury concentration is lowest. In addition, we knew that watershed characteristics may influence mercury concentration in water column, by a renewal water in summer, that why we can think, that the little time of residence of mercury in water column, can explain the low mercury concentration in fish population.

Regarding Study of Rognerud et al., authors explain the low mercury concentrations by : i) a trophic level low of fish population studied, ii) a flow of $\mathrm{Hg}$ in sediments low, and iii) a low rates of methylation in the cold and clear lakes. The two first hypotheses can explain the low level of mercury in fish population. Indeed, in our lakes, and mountain lakes generally, food web is brief. Fish population feeds mainly of insects or, we can observe a phenomenon of cannibalism between species. But, it knew that trophic position influe on mercury contamination and that a fish with a trophic level high will be more contaminated. Consequently, fish population studied here has a trophic level low, combined with a short food web, may explain the low mercury level in fish population. In addition, the watershed composition is mainly composed of rock, consequently, when runoffs join lakes, few little particles and few DOC join water, essential elements for a methylation rates elevated.

Finally, the low mercury concentration in fish population studied here, can be explain by the fact that these lakes are situated in altitude, and that in this region, mercury contamination is mainly due to by atmospheric mercury transport and deposition, and that these lakes are located far away of anthropogenic sources of pollution. This can explain the difference with study conducted in Canada or Amazonia.

\section{Conclusions}

The present article provides the first study on mercury contamination in water column and fish population in the French Alps. We show that $\mathrm{Hg}$ and $\mathrm{MeHg}$ concentration in water lake and fish muscles are very low in comparison to others studies in North-America, but similar with studies conducted in Europe. We explain these results by watersheds compositions and by the fact that in summer, an important water renewal conducted $\mathrm{Hg}$ in direction of effluents, consequently, $\mathrm{Hg}$ cannot reside in water column or to deposit in sediment. A significant effort must be however conducted to identify the source of $\mathrm{Hg}$ and to know mercury distribution in fishes. 
We would like to thank the Conseil Général de l'Isère for its financial support for this study in the frame of the CECALM (Contamination des ECosystème ALpins par le Mercure) project. We thank the Centre National de la Recherche Scientifique (CNRS), the University Joseph Fourier and the Institut Universitaire de France for their financial support. Special thanks also to Bruno Axelrad for his help in the field at Lake Bramant.

\section{References}

Amyot M, Gill G, Morel FM. Production and Loss of Dissolved Gaseous Mercury in Coastal Seawater. Environmental Science \& Technology 1997; 31: 3606-3611.

Barbiaz CL, Andren AW. Total concentration of mercury in Wisconsin (USA) lakes and rivers. Water, Air and Soil Pollution 1995; 83: 173-183.

Belger L, Forsberg BR. Factors controlling $\mathrm{Hg}$ levels in two predatory fish species in the Negro river basin, Brazilian Amazon. Sci Total Environ 2006; 367: 451-9.

Bjorklund I, Borg $\mathrm{H}$, Johansson K. Mercury in Swedish lakes-its regional distribution and causes. AMBIO 1984; 13: 118-121.

Blais JM, Charpentie, S., Pick, F., Kimpe, L. E., St Amand, A., Regnault-Roger, C. Mercury, polybrominated diphenyl ether, organochlorine pesticide, and polychlorinated biphenyl concentrations in fish from lakes along an elevation transect in the French Pyrenees. Ecotoxicol Environ Saf 2006; 63: 91-9.

Bloom NS, Crecelius EA. Determination of Mercury in Sea water at Subnanogram per Liter Levels. Marine Chemistry 1983; 14.

Bonzongo JC, Lyons WB. Impact of land use and physicochemical settings on aqueous methylmercury levels in the Mobile-Alabama River System. Ambio 2004; 33: 328-33.

Cai Y, Jaffe R, Azaam Alli A, Jones RD. Determination of organomercury compounds in aqueous samples by capillary gas chromatography-atomic fluorescence spectrometry following solidphase extraction. Analytica chimica ACTA 1996; 334: 251-259.

Celo V, Lean DR, Scott SL. Abiotic methylation of mercury in the aquatic environment. Sci Total Environ 2006; 368: 126-37.

Compeau GC, and Bartha, R. Sulfate-Reducing Bacteria: Principal Methylators of Mercury in Anoxic Estuarine Sediment. applied and environmental microbiology 1985; 50: 498-502.

Drevnick PE, Canfield DE, Gorski PR, Shinneman AL, Engstrom DR, Muir DC, et al. Deposition and cycling of sulfur controls mercury accumulation in Isle Royale fish. Environ Sci Technol 2007; 41: 7266-72.

Driscoll CT, Han Y-J, Chen CY, Evers DC, Fallon Lambert K, Holsen TM, et al. Mercury Contamination in Forest and Freshwater Ecosystems in the Northeastern United States. BioScience 2007; 57: 17-28.

Ferrari CP, Moreau AL, Boutron CF. Clean conditions for the determination of ultra-low levels of mercury in ice and snow samples. Journal of Analytical chemistry 2000; 366: 433-437.

Graydon JA, St Louis VL, Hintelmann H, Lindberg SE, Sandilands KA, Rudd JW, et al. Long-term wet and dry deposition of total and methyl mercury in the remote boreal ecoregion of Canada. Environ Sci Technol 2008; 42: 8345-51.

Grigal DF. Inputs and outputs of mercury from terrestrial watersheds: a review. Environmental research 2002; 10: 1-39. 
Lavigne M, Lucotte M, Paquet S. Relationship between mercury concentratons and growth rates for walleye, northern pike, and lake trout from Quebec lakes (canada). North American Journal of Fisheries Management 2010, In Press.

Lindeberg C, Bindler R, Bigler C, Rosen P, Renberg I. Mercury pollution trends in subarctic lakes in the northern Swedish mountains. Ambio 2007; 36: 401-5.

Lindqvist O, Johansson K, Aastrup M, Andersson A, Bringmark L, Gunnar Hovsenius G, et al. Mercury in the swedish environment - Recent research on causes, consequences and corrective methods. Water, Air and Soil Pollution 1991; 55.

Loseto LL, Lean DR, Siciliano SD. Snowmelt sources of methylmercury to high arctic ecosystems. Environ Sci Technol 2004; 38: 3004-10.

Monson BA, Brezonik PL. Seasonal patterns of mercury species in water and plankton from softwater lakes in Northeastern Minnesota. Biogeochemistry 1998; 40: 147-162.

Pacyna EG, Pacyna JM, Fudala J, Strzelecka-Jastrzab E, Hlawiczka S, Panasiuk D. Mercury emissions to the atmosphere from anthropogenic sources in Europe in 2000 and their scenarios until 2020. Sci Total Environ 2006; 370: 147-56.

Pongratz R, Heumann KG. Production of methylated mercury, lead, and cadmium by marine bacteria as a significant natural source for atmospheric heavy metals in polar regions. Chemosphere 1999; 39: 89-102.

Ribeiro Guevara S, Queimalinos CP, Dieguez Mdel C, Arribere M. Methylmercury production in the water column of an ultraoligotrophic lake of Northern Patagonia, Argentina. Chemosphere 2008; 72: 578-85.

Rognerud S, Grimalt JO, Rosseland BO, Fernadez P, Hofer R, Lackner R, et al. Mercury and organochlorine contamination in brown trout (Salmo trutta) and arctic charr (Salvelinus alpinus) from high mountain lakes in Europe and the Svalbard archipelago. Water, Air, and Soil Pollution 2005: 209-232.

Ward DM, Nislow KH, Chen CY, Folt CL. Rapid, efficient growth reduces mercury concentrations in stream-dwelling Atlantic salmon. Trans Am Fish Soc 2010; 139: 1-10.

Warner KA, Bonzongo JC, Roden EE, Ward GM, Green AC, Chaubey I, et al. Effect of watershed parameters on mercury distribution in different environmental compartments in the Mobile Alabama River Basin, USA. Sci Total Environ 2005; 347: 187-207.

Warner KA, Roden EE, Bonzongo JC. Microbial mercury transformation in anoxic freshwater sediments under iron-reducing and other electron-accepting conditions. Environ Sci Technol 2003; 37: 2159-65. 
Table 1 : Lakes and watershed characteristics.

\begin{tabular}{|c|c|c|c|c|c|c|c|c|c|}
\hline Lakes & Location & $\begin{array}{l}\text { Altitude } \\
\text { (meter) }\end{array}$ & $\begin{array}{c}\text { Lake area } \\
\left(\mathrm{km}^{2}\right)\end{array}$ & $\begin{array}{l}\text { Catchment } \\
\text { area }\left(\mathrm{km}^{2}\right)\end{array}$ & $\%$ of tree & $\begin{array}{c}\% \text { of wild } \\
\text { grass }\end{array}$ & $\%$ of land & $\%$ of rock & $\begin{array}{c}\% \text { of } \\
\text { snow/ice }\end{array}$ \\
\hline Poursollet & $\begin{array}{c}45^{\circ} 03^{\prime} 08^{\prime \prime} \mathrm{N}, \\
E 5^{\circ} 54^{\prime} 00^{\prime \prime} \mathrm{E}\end{array}$ & 1649 & 0.017 & 0,71 & 57,16 & 33,01 & 2,43 & 0,97 & 0,12 \\
\hline Crop & $\begin{array}{c}45^{\circ} 12^{\prime} 28^{\prime \prime} \mathrm{N} \\
5^{\circ} 59^{\prime} 16^{\prime \prime} \mathrm{E}\end{array}$ & 1906 & 0.051 & 1,71 & 4,11 & 48,4 & 10,49 & 15,51 & 1,01 \\
\hline La Sagne & $\begin{array}{c}45^{\circ} 13^{\prime} 15^{\prime \prime} \mathrm{N} \\
\mathrm{E} 6^{\circ} 04^{\prime} 33^{\prime \prime} \mathrm{E}\end{array}$ & 2067 & 0.065 & 11,19 & 0,31 & 13,47 & 8,8 & 62,48 & 3,64 \\
\hline Bramant & $\begin{array}{c}45^{\circ} 12^{\prime} 00^{\prime \prime} \mathrm{N} \\
\mathrm{E} 6^{\circ} 10^{\prime} 34^{\prime \prime} \mathrm{E}\end{array}$ & 2448 & 0.144 & 5,81 & 0,78 & 9,33 & 7,59 & 40,74 & 36,85 \\
\hline
\end{tabular}




\begin{tabular}{|c|c|c|c|c|c|}
\hline Variable & Unit & $\mathrm{n}$ & Mean & SE & range \\
\hline \multicolumn{6}{|l|}{ Poursollet } \\
\hline Length & $\mathrm{mm}$ & 7 & 277 & 28.9 & $230-300$ \\
\hline Weight & g & 7 & 322 & 197 & $273-374$ \\
\hline Age & $\mathrm{yr}$ & 7 & 6.42 & 0.66 & $4-8$ \\
\hline $\mathrm{THg}$ & $\mathrm{mg} \cdot \mathrm{kg}^{-1}$ & 7 & 0.10 & 0.039 & $0.07-0.16$ \\
\hline $\begin{array}{c}\text { THg predicted } \\
\text { ( st. length of } 210 \mathrm{~mm} \text { ) }\end{array}$ & $\mathrm{mg} \cdot \mathrm{kg}^{-1}$ & 7 & 0.14 & / & I \\
\hline \multicolumn{6}{|l|}{ Crop } \\
\hline Length & $\mathrm{mm}$ & 35 & 192 & 12.9 & $130-620$ \\
\hline Weight & g & 35 & 285 & 88 & $24-4000$ \\
\hline Age & $\mathrm{yr}$ & 35 & 4.97 & 0.29 & $3-12$ \\
\hline $\mathrm{THg}$ & $\mathrm{mg} \cdot \mathrm{kg}^{-1}$ & 35 & 0.19 & 0.017 & $0.009-0.65$ \\
\hline $\begin{array}{c}\text { THg predicted } \\
\text { ( st. length of } 210 \mathrm{~mm} \text { ) }\end{array}$ & $\mathrm{mg} \cdot \mathrm{kg}^{-1}$ & 35 & 0.21 & / & / \\
\hline \multicolumn{6}{|l|}{ La Sagne } \\
\hline Length & $\mathrm{mm}$ & 21 & 213 & 16.7 & $135-520$ \\
\hline Weight & g & 21 & 191 & 113 & $38-2300$ \\
\hline Age & $\mathrm{yr}$ & 21 & 5.33 & 0.38 & $4-8$ \\
\hline $\mathrm{THg}$ & $\mathrm{mg} \cdot \mathrm{kg}^{-1}$ & 21 & 0.20 & 0.022 & $0.06-0.75$ \\
\hline $\begin{array}{c}\text { THg predicted } \\
\text { ( st. length of } 210 \mathrm{~mm} \text { ) }\end{array}$ & $\mathrm{mg} \cdot \mathrm{kg}^{-1}$ & 21 & 0.19 & / & I \\
\hline \multicolumn{6}{|l|}{ Bramant } \\
\hline Length & $\mathrm{mm}$ & 46 & 208 & 11.2 & $135-275$ \\
\hline Weight & g & 46 & 124 & 77 & $27-272$ \\
\hline Age & $\mathrm{yr}$ & 46 & 4.58 & 0.25 & $2-10$ \\
\hline $\mathrm{THg}$ & $\mathrm{mg} \cdot \mathrm{kg}^{-1}$ & 46 & 0.097 & 0.015 & $0.03-0.25$ \\
\hline $\begin{array}{c}\text { THg predicted } \\
\text { ( st. length of } 210 \mathrm{~mm} \text { ) }\end{array}$ & $\mathrm{mg} \cdot \mathrm{kg}^{-1}$ & 46 & 0.083 & / & / \\
\hline
\end{tabular}
predicted, for a standard length of $210 \mathrm{~mm}$ is shown.

Table 2: Characteristics for fish population and mercury concentrations in fish muscles. THg predicted, for a standard length of $210 \mathrm{~mm}$ is shown. 
Figure 1 : Map of watershed composition of Crop lake (a), La Sagne lake (b), Poursollet Lake (c) and Bramant lake (d).

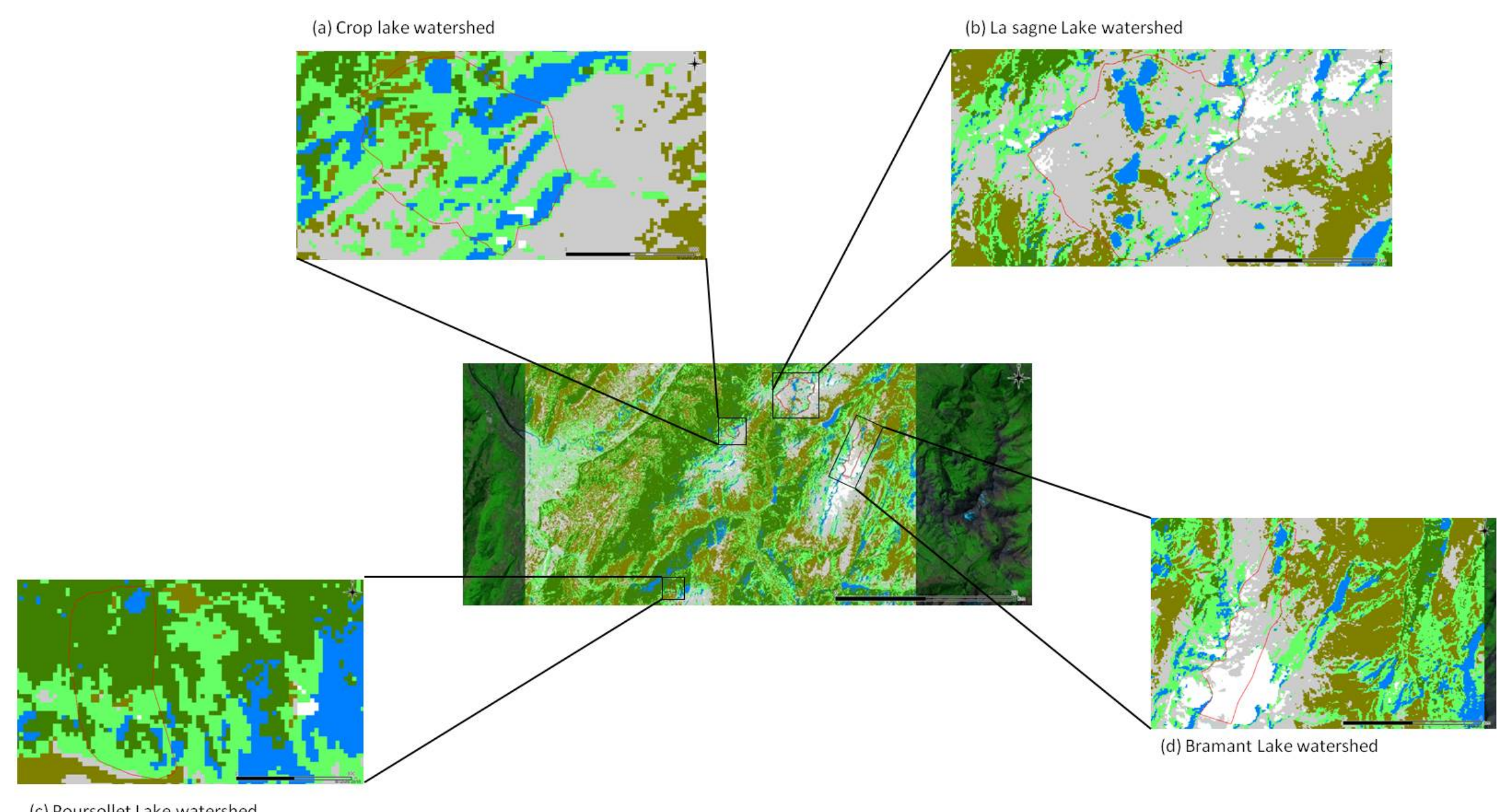

(c) Poursollet Lake watershed 
390

391

392

393

394

395

396

397

398

399

400

401

402

403

404

405

406

407

408

409

410

411

412

413

414

415

416

417

418

419

420

421

422

423

424

425

426

427

Figure 2 : THg and MeHg profiles in $\mathrm{ng} \cdot \mathrm{L}^{-1}$ in water column $(-)$ represent THg and (---)represent MeHg profiles.

(a) Bramant Lake profile

THg concentration in ng. $\mathrm{L}^{-1}$

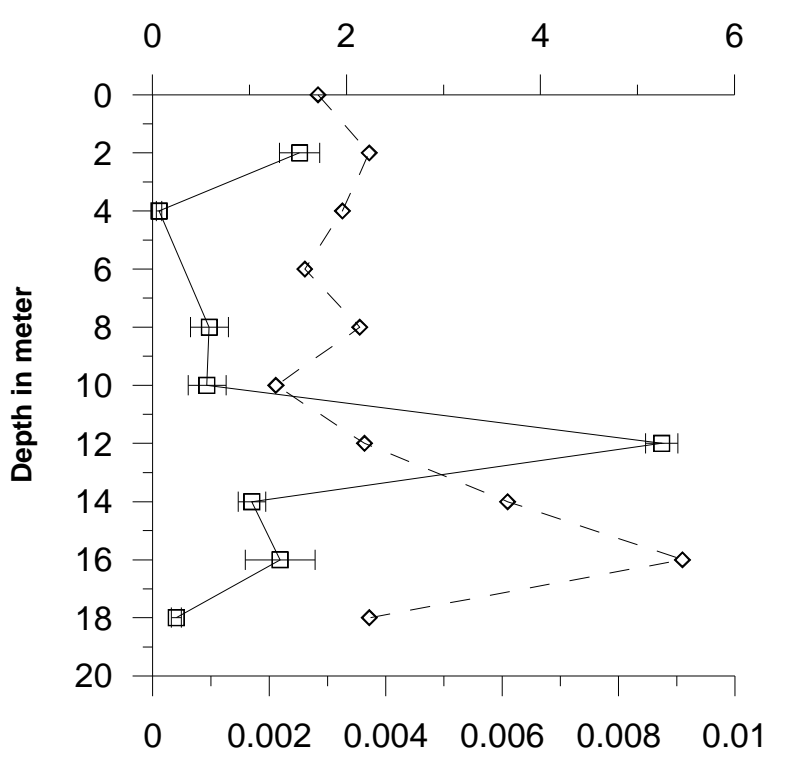

MeHg concentration in pg. $\mathrm{L}^{-1}$

(c) La Sagne Lake profile

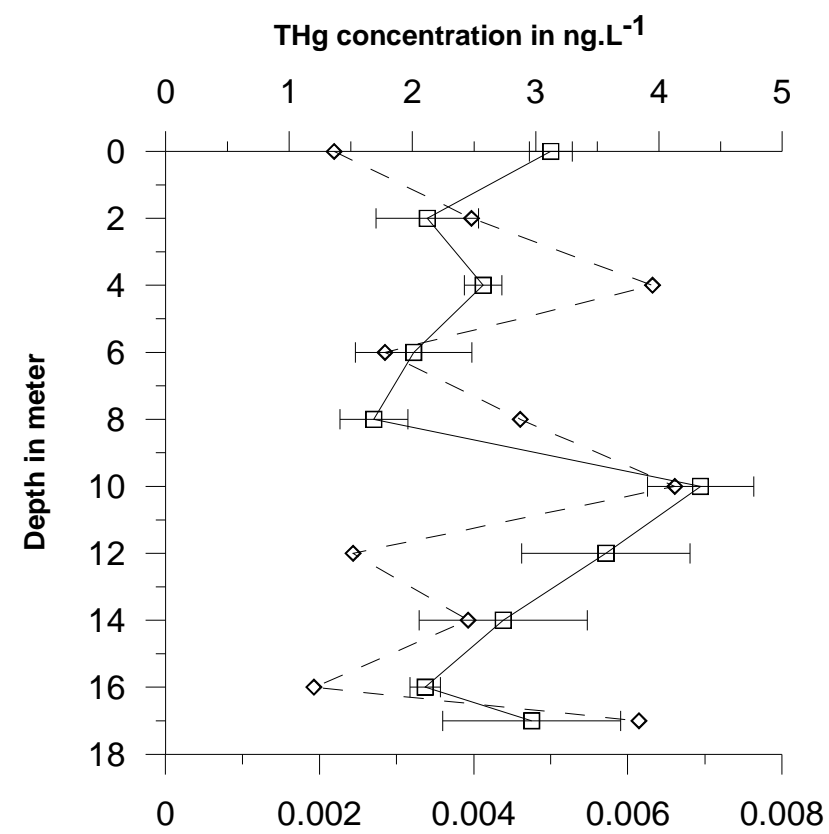

MeHg concentration in pg. $\mathrm{L}^{-1}$ (b) Crop Lake profile

THg concentration in ng. $\mathrm{L}^{-1}$

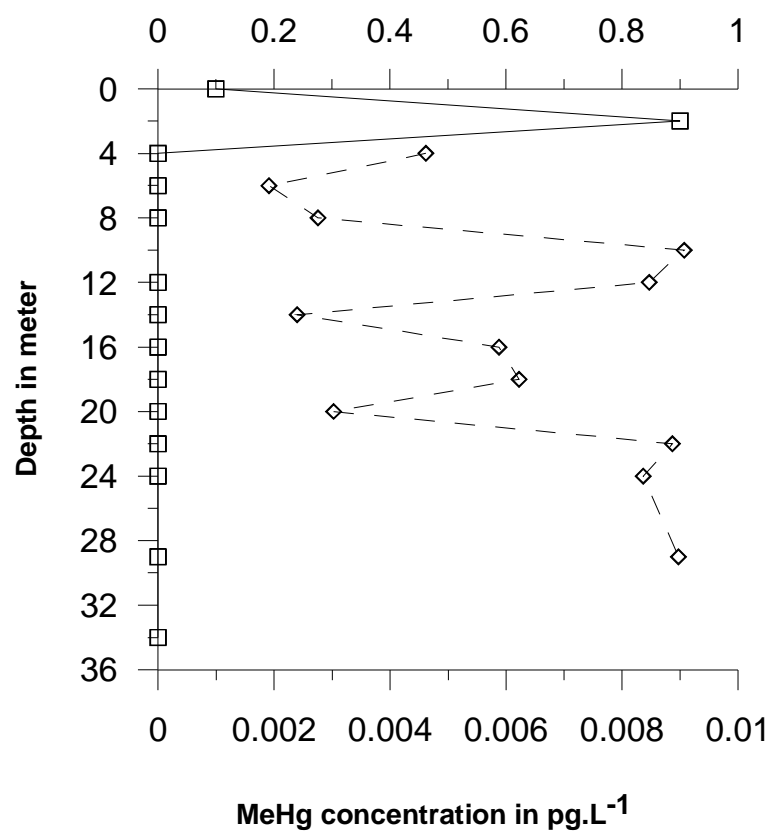

(d) Poursollet Lake profile

THg concentration in ng. $\mathrm{L}^{-1}$

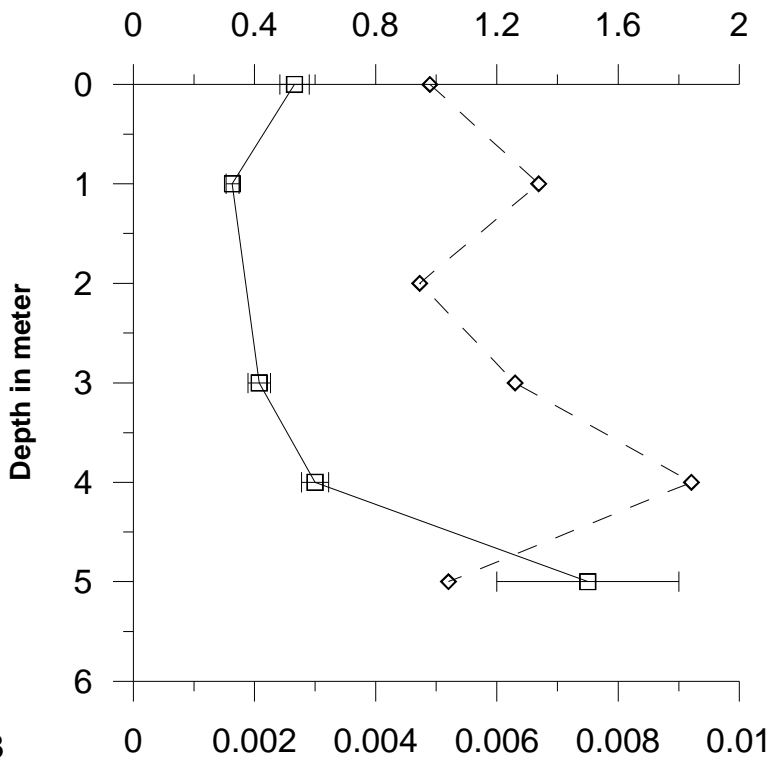

MeHg concentration in pg. $\mathrm{L}^{-1}$ 
428 Figure $3:$ THg concentration in fish population for a standard length of $210 \mathrm{~mm}$ 429

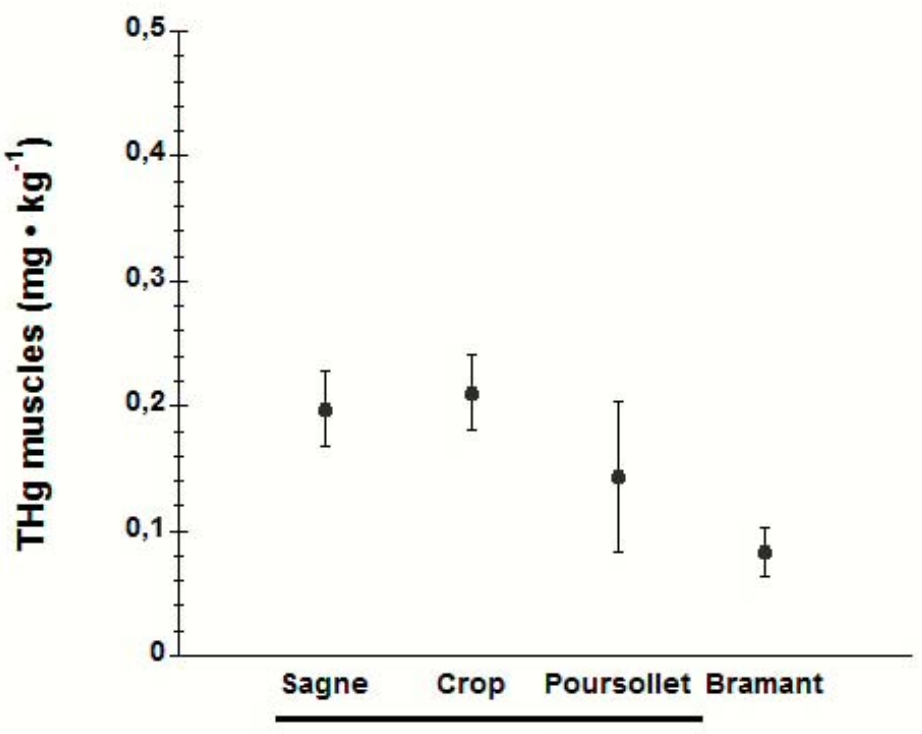

430 